\title{
KARAKTERISTIK NUTRISI SUSU KERBAU BELANG TORAJA, MAKASSAR
}

\author{
Hasria Alang *1, Joni Kusnadi ${ }^{2}$, Tri Ardyati ${ }^{3}$, Suharjono ${ }^{3}$ \\ ${ }^{1}$ Biology, STKIP-PI Makassar, Indonesia \\ ${ }^{2}$ Department of Agriculture Technology, Faculty of Agriculture Technology, \\ Brawijaya University, Malang, Indonesia \\ ${ }^{3}$ Department of Biology, Faculty of Mathematics and Natural Sciences, \\ Brawijaya University, Malang, Indonesia
}

\begin{abstract}
ABSTRAK
Penelitian ini bertujuan untuk menganalisis kandungan nutrisi susu Kerbau Belang Toraja. Metode penelitian ini adalah mengambil sampel susu Kerbau Belang Toraja di kab Toraja Sulawesi Selatan selanjutnya sampel dimasukkan dalam cool box untuk analisis kandungan nutrisinya. Kandungan nutrisi sampel dianalisis menggunakan Lactoscan analyzer untuk melihat kandungan air, kadar abu, protein, lemak, lakosa dan BKTL. Hasil penelitian menunjukkan kandungan nutrisi susu kerbau Belang Toraja terdiri atas protein $(3,17 \%)$, lemak $(12,97 \%)$, laktosa $(4,37 \%)$, kadar air $(79,49 \%)$, kadar abu $(0,88 \%)$ dan SNF/BKTL $(8,42 \%)$.
\end{abstract}

Kata kunci: Kerbau Belang, Lactozcan, Nutrisi.

\section{ABSTRACT \\ NUTRITION \\ CHARACTERISTICS OF BUFFALO MILK FROM TORAJA, MAKASSAR. The study was conducted to analyze the nutritional content of milk in Toraja Belang Buffalo. The research method took samples of Toraja Belang buffalo milk in Toraja Regency, South Sulawesi. Sample was put at the cool box before analyzing its}

*Kosepondensi (corresponding author) Email: hasriaalangbio@gmail.com nutritional content. The nutrient content of the milk sample was analyzed using a Lacto scan analyzer to see water content, ash content, protein, fat, lactose and BKTL. The results showed that nutritional content of Belang Toraja buffalo milk consisted of protein $(3.17 \%)$, fat $(12.97 \%)$, lactose $(4.37 \%)$, water content $(79.49 \%)$, ash content $(0.88 \%)$ and SNF / BKTL (8.42\%).

Keyword: Belang Buffalo, Lacto scan, milk nutrion.

\section{PENDAHULUAN}

Susu adalah sekresi ambing hewan yang mempunyai nilai gizi yang sempurna serta merupakan sumber protein hewani paling baik (Wardana, 2012). Permintaan bahan pangan asal ternak seperti susu, dewasa ini semakin mengalami peningkatan dikarenakan kesadaran masyarakat untuk hidup sehat, tetapi produksi susu dalam negri belum memenuhi kebutuhan masyarakat (Maluhima et al., 2019). Susu merupakan suatu emulsi lemak dalam air yang mengandung beberapa senyawa terlarut, meliputi air $(87,5 \%)$, gula susu atau laktosa 
$(5 \%)$, protein $(3,5 \%)$ dan lemak (3-4\%)

(Widodo, 2002; Yuniati dan Sahara, 2012; Wardana, 2012). Kadar lemak susu kerbau baik tipe perah maupun tipe daging berkisar 6,6 - 9,0\% sedangkan kadar lemak susu sapi 3,6 - 4,9\%. Kadar lemak yang tinggi pada susu kerbau menyebabkan rendahnya peminat meminum susu kerbau karena menyebabkan terjadinya diare apabila dikonsumsi dalam jumlah yang banyak. Selain itu, persedian susu kerbau sangat terbatas, tidak ada pemasaran serta umumnya dibuat menjadi produk yang spesifik seperti Dali di Sumatera Utara, Dadih di Sumatera Barat (Ibrahim, 2008), Dangke di Sulawesi Selatan, maupun susu goreng di NTT (Bamualim dan Zulbandri, 2007), Salah satu hewan penghasil susu adalah kerbau Belang yang ada di Kab Toraja (selanjutnya disebut Kerbau Belang Toraja). Hewan ini merupakan kerbau pedaging atau kerbau lumpur/swamp buffalo sehingga menghasilkan jumlah susu yang lebih kecil jumlahnya yaitu $1-1,5$ L/hari (Hasinah dan Handirawan, 2007; Wirdahayati, 2007; Bamualim et al., 2008) dan telah ditetapkan sebagai hewan endemik di Kabupaten Toraja (Thalib et al., 2014). Kerbau Belang sama halnya dengan Kerbau di Sumatera Barat maupun Sapi Bali, yang merupakan bukan tipe perah, tetapi menurut Ibrahim (2008) dan Suriasih (2015) bahwa hewan tersebut juga dapat dijadikan sebagai sumber susu selain sapi
Frisian Holsten (FH). Hal ini juga berlaku pada susu Kerbau Belang yaitu dapat dijadikan sebagai sumber protein hewani guna pemenuhan asupan nutrisi dan gizi keluarga (Rompis et al., 2013 dan Alang, 2019).

Kerbau Belang mempunyai kedudukan dan peranan penting dalam kehidupan sosial masyarakat Toraja dan etnis lain yang tinggal di sekitar Tana Toraja, terutama sebagai persembahan pada upacara kematian (rambu solo) atau kelahiran dan pernikahan (rambu tuka) (Rizal et al., 2007; Anshar, 2013). Hewan ini juga digunakan dalam transaksi seperti jual beli tanah, kotorannya digunakan sebagai pupuk tanaman, dan beberapa masyarakat ada yang mengonsumsi susu kerbau untuk pemenuhan gizi keluarga (disebut Pangngandu), sehingga hewan ini memiliki harga yang mahal terutama yang jantan (Bamualim dan Zulbandri, 2007; Matandung et al., 2007; Said dan Tappa, 2008). Pemotongan kerbau Belang yang cukup tinggi, mencapai 50-60 ekor per tahun sedangkan kelahiran hanya 10-20 ekor per tahun menyebabkan populasi ini semakin berkurang sehingga akan mengancam kepunahan kerbau belang (Said dan Tappa, 2008). Subdinas Peternakan dan Perikanan Toraja (2010) menyatakan populasi kerbau Belang di Toraja Utara telah mengalami penurunan, yaitu tahun 2008 sebanyak 3.582 ekor, 
2009 sebanyak 3.486 ekor dan 2010 menjadi 3.030 ekor. Hal ini dikhawatirkan akan menyebabkan berkurangnya salah satu sumber protein hewani. Selain itu, Oka et al. (2017) menyatakan bahwa adanya peningkatan perminataan akan susu mendorong diperlukannya pengkarakteristikan dari susu tersebut. Salah satunya adanya karakteristik kimiawi seperti kandungan nutrisi pada susu. Hal ini dimaksudkan agar kepercayaan konsumen terhadap susu dapat dipertahankan. Hal inilah yang melatarbelakangi dilakukannya penelitian ini, dikarenakan penelitian mengenai kandungan nutrisi pada susu Kerbau Belang Toraja belum pernah dilaporkan, sehingga penelitian ini layak dilakukan sebagai salah satu upaya ekplorasi hewan tersebut agar keberadaannya tetap lestari.

\section{MATERI DAN METODE PENELITIAN}

Sampel yang digunakan dalam penelitian ini adalah susu segar Kerbau Belang yang diambil di Kabupaten Tana Toraja Sulawesi Selatan pada bulan Oktober 2016. Pengambilan sampel dilakukan dengan cara pemerahan secara manual (tangan). Metode pemerahan dilakukan dengan cara membersihkan ambing Kerbau Belang terlebih dahulu menggunakan air hangat. Susu segar ditampung dalam ember yang telah disterilkan, setelah itu, dimasukkan dalam botol ulir steril dan disimpan dalam cool box yang berisi ice gel agar susu menjadi awet.

Uji kandungan nutrisi susu Kerbau Belang dilakukan di Laboratorium Perah Fakultas Peternakan, Unversitas Brawijaya Malang. Kandungan nutrisi sampel susu Kerbau Belang Toraja dianalisis menggunakan Lactoscan Analyzer, dengan cara pipa analisis dan probe $\mathrm{pH}$ meter dimasukkan ke dalam sampel, sehingga hasil analisa akan muncul di layar monitor Lactoscan tersebut. Nutrisi yang dideteksi berupa kadar air, kadar abu, protein, lemak, laktosa, dan SNF/BKTL.

\section{HASIL DAN PEMBAHASAN}

\section{Codex Susu}

Susu merupakan komoditi pangan yang standarnya diatur oleh Codex atau Codex Alimentarius Commission (CAC). Susu Kerbau Belang Toraja telah dikarakterisasi kandungan nutrisinya menggunakan Lactoscan analyzer, meliputi protein, lemak, laktosa, air, kadar abu dan SNF/BKTL (Tabel 1). Standar lemak menurut Codex adalah 2,75\% dan BKTL $8 \%$, sedangkan Direktorat Gizi Depkes RI menyatakan nilai kadar lemak 
Tabel 1. Karakteristik Nutrisi Susu Kerbau Belang Toraja (Hasil Penelitian) Dibandingkan Susu Hewan Lain

\begin{tabular}{lllllll}
\hline Nutrisi & $\begin{array}{l}\text { Kerbau. } \\
\text { Belang }\end{array}$ & Kerbau $^{\text {a) }}$ & Sapi $^{\text {a) }}$ & Kambing $^{\text {a) }}$ & Domba $^{\text {b) }}$ & Kuda $^{\text {b) }}$ \\
\hline Kadar air (\%) & 79,49 & 83,10 & 86,10 & 88,20 & 81,3 & 89,9 \\
Kadar abu (\%) & 0,88 & 0,78 & 0,74 & 0,78 & 1,0 & 0,3 \\
Protein (\%) & 3,17 & 3,80 & 3,20 & 3,40 & 5,6 & 1,8 \\
Lemak (\%) & 12,97 & 7,40 & 3,40 & 4 & 6,9 & 1,2 \\
Laktosa (\%) & 4,37 & 4,90 & 4,60 & 3,60 & 5,2 & 6,9 \\
SNF/BKTL (\%) & 8,42 & - & - & - & - & - \\
\hline Kem/Brand
\end{tabular}

Keterangan: (-) belum dilaporkan

a) Saleh (2004)

b) Einsmiger (1971)

susu $3,5 \%$. Codex susu adalah suatu daftar satuan yang harus dipenuhi air susu sebagai bahan pangan. Daftar ini telah disepakati para ahli gizi dan kesehatan sedunia, walaupun di setiap negara atau daerah mempunyai ketentuan-ketentuan tersendiri.

\section{Kandungan Nutrisi Susu Kerbau Belang}

Penelitian menggunakan susu kerbau jenis Kerbau Rawa (lumpur) dan Kerbau Sungai di Sumatera Utara telah dilakukan Damayanti et al. (2014) dan Suariasih (2015). Pada penelitian tersebut, Damayanti et al. (2014) memperoleh data bahwa pada kerbau rawa (lumpur) kandungan protein, lemak, dan BKTL berturut-turut yaitu $5,14 \%, 7,23 \%$ dan $10,61 \%$ sedangkan kerbau sungai memiliki kandungan protein, lemak, dan BKTL berturut-turut yaitu $4,68 \%, 4,13 \%$ dan 11,5\%. Penelitian Suriasih (2015) menyatakan bahwa pada kerbau rawa (lumpur) kandungan protein, lemak, dan BKTL berturut-turut yaitu 5,14\%, 7,23\% dan $81,87 \%$ sedangkan kerbau sungai memiliki kandungan protein, lemak, dan BKTL berturut turut yaitu 4,68\%, 4,13\% dan $80,33 \%$. Hasil penelitian pada Tabel 1 menunjukkan bahwa kandungan protein dan air dari susu kerbau Belang Toraja lebih rendah dibandingkan dengan penelitian Damayanti et al. (2014) dan Suariasih (2015) terhadap kerbau Rawa dan kerbau Sungai di Sumatera Utara, namun kandungan lemak susu kerbau Belang Toraja pada studi ini lebih tinggi dibandingkan hasil penelitian Damayanti et al. (2014) dan Suriasih (2015). Standar Nasional Indonesia/SNI (2011) mensyaratkan kadar lemak pada susu sebesar 3,0\%. Kadar lemak yang tinggi menyebabkan energi pada susu kerbau lebih tinggi dibandingkan dengan susu sapi, namun hal ini menyebabkan rendahnya 
peminat terhadap susu kerbau karena kandungan lemak yang tinggi dapat menyebabkan terjadinya diare (Bamualim dan Zulbandri, 2007).

\section{Penyebab Kadar Lemak Tinggi Susu Kerbau Belang Toraja}

Kadar lemak yang tinggi pada susu kerbau disebabkan kerbau membuang kelebihan lemak dari tubuhnya ke dalam susunya. Selain itu, Tinggi atau rendahnya kadar lemak dalam susu, sangat dipengaruhi oleh umur laktasi dan interval serta waktu pemerahan serta kualitas pakan yang diberikan. Prosedur dan interval pemerahan susu juga sangat berpengaruh terhadap kadar lemak susu tersebut. Saat pengambilan sampel susu pada penelitian ini, umur kerbau tersebut telah memasuki fase kering. Fase kering adalah fase menjelang akhir laktasi, dan fase laktasi biasanya berlangsung hingga bulan ketiga setelah proses kelahiran. Saat fase kering, produksi susu akan menurun dan kandungan lemak pada susu meningkat. Selain itu, waktu pemerahan yang dilakukan pada siang hari juga menyebabkan kadar lemak susu menjadi tinggi. Interval yang lebih lama dapat menurunkan kadar lemak pada pemerahan berikutnya, sebaliknya semakin pendek jarak pemerahan maka mengakibatkan kadar lemak semakin tinggi. Pemerahan 34 kali sehari akan meningkatkan kadar lemak lebih tinggi dibandingkan hanya 2 kali sehari. Hal inilah yang menyebabkan tingginya kandungan lemak pada susu Kerbau Belang Toraja tersebut.

Pakan merupakan aspek yang penting dalam usaha ternak kerbau karena akan menentukan kelangsungan hidupnya. Pakan ini dapat berupa hijauan maupun konsentrat dan sangat berpengaruh terhadap zat gizi susu sehingga akan memengaruhi kualitas susu yang dihasilkan. Pakan yang mengandung karbohidrat, ketika berada di dalam rumen akan di ubah menjadi Volatile Fatty Acid (VFA). Volatile Fatty Acid ini kemudian dipecah menjai asetat, butirat dan propionat. Semakin meningkat kadar propionat maka kadar glukosa akan semakin tinggi, menyebabkan kadar laktosa semakin tinggi, dan produksi susu semakin tinggi pula (Imannto et al., 2018). Pemberian konsentrat menyebabkan komposisi lemak susu akan semakin menurun. Hal ini disebabkan kandungan protein yang cukup tinggi dalam konsentrat memacu produksi asam propionat (Saleh, 2004; Sumantri et al., 2005; Ace dan Wahyuningsih, 2010; Zurriyati et al., 2011; Kurniawan et al., 2012; Sukmawati, 2014). Mineral berupa sulfur yang terkandung dalam pakan/ransum dapat meningkatkan kadar lemak susu. Hijauan tanaman akan meningkatkan sintesis asam lemak sehingga meningkatkan kadar lemak susu. 
Hijauan tanaman mengandung banyak asam asetat yang merupakan bahan baku sintesis asam lemak. Semakin banyak asam asetat yang disintesis, maka asam lemaknya akan semakin tinggi, sehingga konsentrasi lemak akan semakin tinggi pula. Berdasarkan hasil penelitian, maka susu Kerbau Belang Toraja belum memenuhi sebagai sumber lemak yang baik, diakibatkan kandungan lemak yang tinggi pada susu kerbau tersebut, yaitu 12,97\%.

Pemberian pakan konsentrat murni hampir tidak dijumpai di lokasi penelitian. Konsentrat yang diberikan berupa dedak padi yang dicampur dengan cacahan rumput. Umumnya, peternak Kerbau Belang memberikan pakan berupa hijauan rumput-rumputan dan limbah hasil pertanian. Hijauan rumput-rumputan yang sering diberikan peternak dalam bentuk segar antara lain rumput lapang, rumput gajah, dan rumput alang-alang. Hijauan pakan ternak yang tersedia cukup banyak, karena lahan yang tersedia luas dan potensi iklim yang cukup baik, sehingga hijauan tanaman tersedia sepanjang tahun sehingga dapat memenuhi kebutuhan. Pakan yang berasal dari limbah hasil pertanian diantaranya adalah jerami, daun jagung dan daun ubi jalar. Ketersediaan jerami sangat memadai karena area persawahan cukup luas sehingga limbah hasil persawahan juga cukup banyak. Daun ubi jalar melimpah karena budaya masyarakat lokal yang menanam ubi jalar di pekarangan maupun di kebun. Pemberian pakan hijauan tanaman inilah yang memicu tingginya kadar lemak pada susu Kerbau Belang tersebut, karena pakan mengandung banyak serat yang berfungsi untuk mensintesis asam-asam lemak. Semakin banyak serat yang terkandung dalam suatu pakan, maka sintesis asam lemaknya akan semakin banyak, dan berdampak semakin tinggi kadar lemak pada susu yang dihasilkan. Hal ini berarti, untuk memaksimalkan fungsi susu Kerbau Belang Toraja sebagai minuman, maka diperlukan manajemen pemeliharaan yang baik dari hewan tersebut.

\section{KESIMPULAN}

Kandungan nutrisi susu kerbau Belang Toraja terdiri atas protein $(3,17 \%)$, lemak (12,97\%), laktosa (4,37\%), kadar air $(79,49 \%)$, kadar abu $(0,88 \%)$ dan SNF/BKTL $(8,42 \%)$.

\section{UCAPAN TERIMA KASIH}

Ucapan terima kasih kepada Bapak Dr. Ir.Osfar Sjofjan, M.Sc., IPU. atas peminjaman Laboratorium Perah untuk tempat pengujian sampel susu, serta masukan dan arahannya sehingga 
penelitian ini dapat dilaksanakan dengan baik.

\section{DARTAR PUSTAKA}

Ace, I. S., dan Wahyuningsih. 2010. Hubungan variasi pakan terhadap mutu susu sapi segar di Desa Pasirbucir Kecamatan Caringin Kabupaten Bogor. Jurnal Penyuluhan Pertanian 5(1): 67 - 77.

Alang, H. 2019. Studi Potensi Dan Gen Penyandi Bakteriosin Bakteri Asam Laktat Dari Susu Kerbau Belang (Bubalus bubalis 1.) Tana Toraja Sebagai Kandidat Probiotik. Disertasi. Universitas Brawijaya Malang

Anshar. M. 2013. Pemetaan Potensi Pengembangan Ternak Kerbau Di Selatan. Jurnal Teknosains 7(1): 3339.

Bamualim, A. dan M. Zulbandri. 2007. Situasi dan keberadaan ternak kerbau di Indonesia. Seminar dan Lokakarya Nasional Usaha Ternak Kerbau. LIPI Cibinong. Hal: 32 39.

Bamualim, A., M. Zulbandri dan C. Talib. 2008. Peran dan ketersediaan teknologi pengembangan kerbau di Indonesia. Seminar dan Lokakarya Nasional Usaha Ternak Kerbau. LIPI Cibinong. Hal: 1-10.

Damayanti, E., Y. Yopi, H. Hasinah, T. Setyawardani, H. Rizqiati dan S. Putra. 2014. Karakteristik susu Kerbau Sungai dan Rawa di Sumatera Utara. Jurnal Ilmu Pengetahuan Indonesia. 19(2): 6773.
Ensminger, M.E. 1971. Dairy Cattle Science. Animal Agriculture Series. 1st Ed. The Inteste Printers and Publishers Inc. Danville3. Illionis.

Hasinah, H. dan E. Handirawan. 2007. Keragaman genetik ternak kerbau di Indonesia. Lokakarya Nasional Usaha Ternak Kerbau Mendukung Program Kecukupan Daging sapi. LIPI Cibinong. Hal: 89 - 95.

Ibrahim, L. 2008. Produksi Susu, Reproduksi dan Manajemen Kerbau Perah di Sumatera Barat. Jurnal Peternakan. 5(1): 1-9.

Imannto, N. Y., D. W. Harjanti dan R. Hartanto. 2018. Kadar Glukosa darah dan laktosa susu pada sap perah dengan pemberian suplemen herbal dan mineral Proteinat. Jurnal Riset Agribisnis Peternakan 3(2): 16-21.

Kurniawan, H., Indrijani dan D. S. Tasripin. 2012. Model kurva produksi susu sapi perah dan korelasinya pada pemerahan pagi dan siang periode laktasi satu. Media Peternakan 29(1): 5-46.

Maluhima, R.J., J. H. Manopo, A. Lomboan, dan S. H. Turagan. 2019. Rekondisi beberapa ukuran tubuh ternak sapi perah Friess Holland di Balai Pengembangan Bibit dan Pakan Ternak. Zootec 39(1): 165170.

Matandung, R., B. Marimbunna dan T. Pawan. 2007. Kearifan Lokal Menjaga Kesehatan Kerbau Belang, Yayasan Jaya Lestari Desa (JALESA) Rantepao dan Yayasan Komunitas Indonesia (YAKOMI) Mamasa.

www.pewartakabaraindonesia.blog spot.com 
Oka, B., M. Wijaya dan Kadirman. 2017. Karakteristik Kimia Susu Sapi Perah di Kabupaten Sinjai. Jurnal Pendidikan Teknologi Pertanian. 3: 195-202.

Rizal, M., Herdis, Yulnawati dan H. Maheshwari. 2007. Peningkatan Kualitas Spermatozoa Epididimis Kerbau Belang yang Dikriopreservasi dengan Beberapa Konsentrasi Sukrosa. Jurnal Veteriner. 8 (4): 188-193.

Rompis, J. E. G., J. F. Paat, M. M. Kawatu dan Demmalona. 2013. Tatalaksana Pemeliharaan Kerbau Belang di Kecamatan Mamasa Kabupaten Mamasa Provinsi Sulawesi Barat. Zootec 33(1): 68-79.

Said, S. dan B. Tappa. 2008. Perkembangan Kerbau Belang (Tedong Bonga) di Puslit Bioteknologi LIPI Cibinong, Jawa Barat dengan teknologi produksi. Seminar dan Lokakarya Nasional Usaha Ternak Kerbau. LIPI Cibinong. Hal: 18-25.

Saleh, E. 2004. Dasar Pengolahan Susu dan Hasil Ikutan Ternak. Program Studi Produksi Ternak Fakultas Pertanian. Buku Bahan Ajar. Universitas Sumatera Utara. Medan

Subdinas Peternakan dan Perikanan Toraja Utara. 2010. Rekapan Populasi Ternak Kabupaten Toraja Utara. Toraja Utara. Dinas Pertanian, Peternakan dan Perikanan Kabupaten Toraja Utara.

Sukmawati, N, S. 2014. Faktor-Faktor Yang Mempengaruhi Susunan dan Keadaan Air Susu. Buku Bahan Ajar. Laboratorium Ilmu Ternak Perah Fakultas Peternakan Universitas Udayana Denpasar.
Sumantri, S. R., R. A. Maheswari, A. Anggraeni, K. Dwiyanto dan A. Farajallah. 2005. Pengaruh genotipe Kappa Kasein (K-Kasein) terhadap kualitas susu pada sapi perah FH Di BPTU Baturraden. Seminar Nasional Teknologi Peternakan dan Veteriner. Fakultas Peternakan Intitut Pertanian Bogor. Bogor

Suriasih, K. 2015. Minuman Probiotik "Kefir" Susu Sapi Bali Meningkatkan Imunitas dan Mencegah Penyakit Degenerative. Udayana University Press. ISBN : 978602-294-033-3.

Wardana, A. S. 2012. Teknologi Pengolahan Susu. Fakultas Teknologi Pertanian. Buku Bahan Ajar. Universitas Slamet Riyadi. Surakarta.

Widodo, W. 2002. Bioteknologi Fermentasi Susu. Pusat Pengembangan Biotekhnologi Universitas Muhammadiyah Malang. 1 - 30.

Wirdahayati, R. B. 2007. Upaya Peningkatan Produksi Susu Kerbau Untuk Kelestarian Produk Dadih di Sumatera Barat. Jurnal Wartazoa 17(4): $178-184$

Yuniati, H. dan E. Sahara. 2012. Komponen bioaktif protein dan lemak dalam susu kuda liar. Buletin Penelititian Kesehatan 40(2): $66-74$

Zurriyati, Y., R. R. Noor dan R. R. A. Maheswari. 2011. Analisis molekuler genotipe Kappa Kasein (K Kasein) dan komposisi susu kambing Peranakan Etawah, Saanen dan persilangannya. Jurnal Ilmu Ternak dan Veteriner 16 (1) : 61-70. 